\title{
Road Quality in Indonesia: Is It Linked to Special Allocation Funds and Political Competition?
}

\author{
Putri Natalia Saragih ${ }^{1}$, Khoirunurrofik Khoirunurrofik ${ }^{2 *}$ \\ ${ }^{1,2}$ Faculty of Economics and Business, Universitas Indonesia, Jakarta, Indonesia \\ E-mail: ${ }^{1}$ putrinatalia244@gmail.com, ${ }^{2}$ khoirunurrofik@ui.ac.id
}

*Corresponding author

\section{$\mathrm{H} 72$ \\ $\mathrm{H} 77$ \\ $\mathrm{O} 21$ \\ $\mathrm{O} 23$ \\ R53}

JEL Classification:

Received: 16 June 2021

1' Revision: 07 August 2021

$2^{\text {nd }}$ Revision: 09 September 2021

Accepted: 28 November 2021

\begin{abstract}
This study aims to determine the relationship between decentralization, viewed from a fiscal and political perspective, and the quality of road infrastructure in Indonesian regions. This study uses panel data of 32 provinces in Indonesia in the 2011-2018 and applied pooled ordinary least square (OLS) estimation with individual fixed-effects to capture time-variable estimation. The results show that special allocation funds $(D A K)$ did not significantly improve the quality of damaged roads, although the correlation was negative. The apparent improvement in the damaged-road ratio is presumed to be because the government is currently more focused on the physical construction of roads than on maintenance, so the level/quality of road maintenance is still not optimal. The political competition was found to be negatively related to the improvement of the damaged-road ratio, indicating that political competition improved the quality of budget execution in road infrastructure provision.
\end{abstract}

\section{Keywords:}

special allocation funds; political competition; road quality

How to Cite:

Saragih, P. N., \& Khoirunurrofik , K. (2022). Road Quality in Indonesia: Is It Linked to Special Allocation Funds and Political Competition? Signifikan: Jurnal Ilmu Ekonomi, 11(1), 57-72. https://doi.org/10.15408/sjie. v11i1.21090. 


\section{INTRODUCTION}

The decentralized political system formally implemented in Indonesia in January 2001 continues to develop. At present, the delegation of authority and regional funding is regulated by Law Number 23 of 2014 concerning regional government, and Law Number 33 of 2004 concerning the financial balance between the central government and regional governments. Various interacting phenomena related to the implementation of decentralization reflect the different political, fiscal, and administrative dimensions present at each government level (Martinez-Vazquez et al., 2017). Through the decentralization scheme, local governments are expected to develop their respective regions, provide access to services for the community, and open up wider employment opportunities to improve the welfare of the community in the long run.

Road infrastructure development is one of the government's priority programs for accelerating development. District roads represent $80 \%$ of total roads and are the primary connectivity mechanism for regional economies. One of the sources of funds for road construction comes from the transfer of funds from the central government through the Special Allocation Fund (DAK). There are two types of DAK, namely physical and non-physical. In terms of objectives, physical DAK has three aspects: regular physical DAK is the fulfillment of basic services and economic equality to improve community welfare quality; assigned physical DAK supports national priorities that are devolved to regional authorities related to predetermined priority activities and locations; finally, affirmative physical DAK accelerates infrastructure and basic services in priority locations but specifically for underdeveloped and border areas.

Regulation of the Minister of Public Works and Public Housing Number 21 of 2017 states that DAK implementation aims to improve the function of the road network as integrated access for potential development areas, especially those in remote, isolated, underdeveloped, and border areas. DAK is prioritized for building activities and maintaining roads regularly. During the period 2010 to 2019, the total realized DAK reached Rp23 trillion. The increase in the number of DAK realizations is also in line with the increasing total length of district roads, which reached 440 thousand $\mathrm{km}$ in 2018 (up from 384 thousand $\mathrm{km}$ in 2009). However, almost 50 percent of total roads are in a non-optimal condition, comprising $16.07 \%$ lightly damaged roads and $24.70 \%$ heavily damaged roads. This is much worse than the situation at national and provincial levels of $3 \%$ and $19 \%$, respectively. At the same time, regional roads have a greater multiplier effect on economic growth than non-regional roads (Fan \& Chan-Kang, 2008). Thus, the relationship between DAK and road quality needs to be investigated further.

Martinez-Vazquez et al., (2017) state that empirical research related to the impact of decentralization on infrastructure services, specifically in terms of the amount of fund allocation and infrastructure-quality outcomes, is still very limited. Research related to the implementation and development of decentralization initially focused more on expenditure and financing mechanisms operating from the center to the fiscal and economic sectors. The implementation of decentralization can strengthen fiscal balance (Eyraud \& Lusinyan, 
2013; Neyapti, 2010) and improve the quality of education (del Granado et al., 2018) and people's access to health services (Apriliani \& Khoirunurrofik, 2020; Bracco et al., 2019; Channa \& Faguet, 2016; Habibi et al., 2003; Jiménez-Rubio, 2011). However, there are indications that if regional capacity is not yet able to manage the budget properly, the impact of decentralization will not be optimal (Ghozali \& Khoirunurrofik, 2020; Lewis, 2017; Neyapti, 2006). A stable fiscal balance is a foundation for local governments to be able to meet community needs. Areas that initially have minimal access to infrastructure seem increasingly focused on increasing investment, especially in the health sector and physical infrastructure (Kis-Katos \& Sjahrir, 2017). However, there is a tendency for regions to use their revenue for other activities rather than for investments whose financing has been regulated by the central government. The direct impact of total local revenue will be lower if the use of transfer funds increases (Kappeler et al., 2013).

Other research is increasingly examining the impact of the amount of investment and the quality of the available public services. Fiscal decentralization can positively impact infrastructure quality (Escaleras \& Calcagno, 2018; Kis-Katos \& Sjahrir, 2017). However, several studies have shown that budget decentralization has not positively impacted the Indonesian context (Lewis, 2017). Budget decentralization can be measured in terms of the scale of its use, and of its outcomes as measured through service quality. A decrease in marginal return will appear when an investment is carried out continuously, although it still positively impacts the economy (S. Fan \& Chan-Kang, 2008).

In fiscal decentralization schemes in Indonesia, physical DAK is one of the sources of financing for road construction and maintenance. An increase in the number of DAKs will support the achievement of priority programs intended to provide adequate infrastructure in the regions. Initially, DAK allocation used a top-down formulation, in which the central government determined the amount of budget allocated to each area (known as a "formula-based" process). In practice, such a concept delivered ineffective and inefficient results. The mismatch of information received by the central government resulted in imprecise allocation both in terms of budget amount and location. In such conditions, the budget is absorbed more slowly and is not even absorbed to the full extent. Therefore, since 2016, DAK allocations have been compiled on a bottom-up basis, in which local governments submit proposals regarding the necessary funding requirements (known as a "proposal-based" process). With this approach, budget absorption will be more effective and efficient. Local governments are assumed to have more information about their regions' needs and so to be better able to adjust budget planning to optimize the provision of infrastructure access.

Apart from budget execution, it should be noted that a conducive political process is also an influencing factor in decentralization success. The political process was formed to meet the needs of a political decentralization scheme that aims to increase local governments' responsiveness to their communities' needs. The top-down accountability mechanism is expected to create better conditions because of the bond between elected leaders and the community, and it is hoped that this concept can improve public services. However, suppose the regional government is more strongly controlled by the political elite 
than the central government, due to weak political accountability mechanisms. In that case, the quality and quantity of public services will not improve (World Bank, 2017). Thus it is clear that the better the political process, the more effective and efficient fiscal implementation will be.

The planning, stipulating, and implementing of budgets is closely related to the political processes formed as a result of political decentralization, processes heavily influenced by centrifugal pressure and separatist movements and socio-political tensions among the regions (Martinez-Vazquez et al., 2017). The delegation of authority from central government to local officials who are directly elected by the community impacts increasing on the number of parties and candidates contending for leadership roles. The chances of being selected depend on the degree to which the community believes in the performance of local government. As a result, political competition will be tighter, and local governments will always strive to improve their performance to ensure re-election in the next period. Increasingly strong political competition can increase the efficiency of budget execution (Bracco et al., 2019) and positively impact the economy (Rezki, 2018).

Political decentralization gives rise to political competition in which direct election by the community opens up opportunities for many political parties and increases the available choices for people at a more local level. This increasing political competition will encourage local governments to be more responsive (and vice versa). Thus, it is assumed that with the existence of political competition, local government performance will improve and so will service to the community. However, there are indications that there is interference in the political process in the planning and budget-execution processes, which indirectly impacts the quality of public services (Rahmawati \& Khoirunurrofik, 2021). The number of parties involved in the political process will lead to more preferences that must be included in decision-making if the results of existing processes are to achieve the best utility for many parties. This indicates that the stronger the political competition that is formed, the better the quality of government performance will be (Albornoz \& Cabrales, 2013). However, if the political process is weakly competitive, loopholes will be created for budget distortion (Skoufias et al., 2011; Wiguna \& Khoirunurrofik, 2021). In addition, even if local government involvement increases, if accountability is still not solid, the may hamper the system of nationalizing political parties (Dell'Anno $\&$ Teobaldelli, 2015; Fan et al., 2009).

Political decentralization has a vital role to play in the quality of infrastructure through the degree of political competition, which can also be illustrated by the extent to which the public trusts the government and political elites. The existence of an electoral system directly results in the expansion of opportunities for various parties to compete. Greater openness and availability of facilities for the public to convey their aspirations is one factor that has influenced the success of political decentralization, leading to the strengthening of the democratic system. The better the economic growth in a country, the greater the chances of implementing democracy. Also, improving economic conditions can increase public confidence in the government (Ligthart \& Van Oudheusden, 2015). 
Research on decentralization generally focuses on the education and health sectors. This study, therefore, seeks to develop a theme related to the infrastructure sector, because this is also one of the essential services that should be considered. Given the close relationship between fiscal and political aspects of decentralization, this study is to examine the association between DAK (fiscal decentralization) and political competition (political decentralization) relate to Indonesia's quality of road infrastructure in the 2011-2018 period.

This study will contribute to the literature in two folds. First, by measuring the quality of infrastructure using heavily damaged roads, the study provides evidence on how effective DAK for road maintenance is to improve the quality of district roads. Second, the study also observed how political decentralization that measures in terms of the political competition that plays a role in the quality of infrastructure development through the political process of local budgeting decisions.

\section{METHODS}

This study uses panel data with a sample of 32 provinces in Indonesia (all provinces except DKI Jakarta and North Kalimantan due to the limited data available) in the 2011-2018 timeframe and with a fixed-effects approach. This study collects data from the Central Bureau of Statistics (BPS), the CEIC Database, the General Election Commissions (KPU), and the Directorate General of Financial Balance, Ministry of Finance (DJPK). To examine the hypotheses, we specify in equation 1. Detailed measurement variables and data sources are explained in Table 1.

$$
\begin{aligned}
\operatorname{ROAD}_{i t}= & \alpha_{0}+\alpha_{1} \mathrm{DAK}_{i t}+\beta_{1} \text { Polcomp }_{i t}+\alpha_{2} \text { Percap }_{i t}+\alpha_{3} \text { Population }_{i t}+\alpha_{4} \text { Policy }_{i t}+ \\
& \alpha_{5} \mathrm{DAKPol}_{i t}+\alpha_{6} \text { LagRoad }_{i t}+\beta_{2} \mathrm{IDI}_{i t}+\beta_{3} \operatorname{PEXP}_{i t}+\beta_{4} \mathrm{MEXP}_{i t}+\lambda_{i t}+\mathrm{u}_{i}
\end{aligned}
$$

As with the market mechanism, an increase in political parties will result in competition between parties to increase the probability of obtaining seats in parliament. Political competition can be measured by calculating the concentration of political party votes in legislative elections using the Herfindahl Hirschman Index (HHI) and has been used to calculate political competition in several recent studies (Alfano \& Baraldi, 2015; Rezki, 2018). The HHI shows the extent of each party's strength in the district-level legislative elections or political concentration in the district parliament. HHI is in the range of 0 to 1 , where 0 indicates that political concentration is deficient (i.e., political competition is intense) and one indicates that political concentration is high (i.e., political competition is weak). The HHI is obtained by summing the squares of each party's share of votes with the majority vote using the following formula:

$$
\text { Political Concentration Index }{ }_{\mathrm{d}, \mathrm{t}}=\sum \mathrm{Sh}_{\text {Vote }_{\mathrm{p}, \mathrm{d}, \mathrm{t}}^{2}}
$$

Political Concentration Index ${ }_{d, t}$ is an index of the concentration of political parties in district $\mathrm{d}$ year $\mathrm{t}$ obtained from the accumulated squared share of each party's votes $\mathrm{p}$ in district $d$ year $t$, equal to the value of HHI. An HHI value of 1 indicates that the competition that occurs in the selection process is perfect. The competition value is 
subtracted from the HHI index using the following formula to obtain political competition figures:

$$
\text { Political Competition }_{\mathrm{d}, \mathrm{t}}=1 \text { - Political Concentration } \text { Index }_{\mathrm{d}, \mathrm{t}}(3)
$$

Political Competition ${ }_{\mathrm{d}, \mathrm{t}}$ is the political competition figure in regency $\mathrm{d}$ year $\mathrm{t}$, indicating how strong/weak the competition is between political parties in the legislative elections. The presence of political parties with a high concentration in a district indicates that the community's degree of political competition is low and vice versa. Political competition figures in 2009 are used for 2011-2013 data and 2014 for 2014-2018 data. This figure used is the average figure of the political competition of all districts in one province.

Table 1. Variable definition and data sources

\begin{tabular}{|c|c|c|}
\hline Variables & Variable definition, data sources & $\begin{array}{l}\text { Expected } \\
\text { sign }\end{array}$ \\
\hline Road Ratio (ROAD) & $\begin{array}{l}\text { The ratio between the length of district damaged roads to the total length of } \\
\text { district roads, CEIC Database. }\end{array}$ & \\
\hline $\begin{array}{l}\text { Special Allocation } \\
\text { Fund (DAK) }\end{array}$ & $\begin{array}{l}\text { The ratio between DAK realization in the road sector and the length of district } \\
\text { roads to adjust for variations in DAK allocation and road lengths in each district; } \\
\text { the potential for reverse causality is anticipated using a lag time of } 1 \text { year earlier, } \\
\text { Directorate General of Financial Balance, Ministry of Finance (DJPK). }\end{array}$ & $(-)$ \\
\hline $\begin{array}{l}\text { Political competition } \\
\text { (Polcomp) }\end{array}$ & $\begin{array}{l}\text { Illustrate the extent of political competition between parties based on the } \\
\text { number of valid votes during the } 2009 \text { and } 2014 \text { DPRD representative elections, } \\
\text { General Election Commissions (KPU). }\end{array}$ & $(-)$ \\
\hline $\begin{array}{l}\text { Income per capita } \\
\text { (Percap) }\end{array}$ & $\begin{array}{l}\text { Reflects perceptions of the higher the income per capita, the more road use will } \\
\text { increase, indirectly due to greater economic activity, Central Bureau of Statistics } \\
\text { (BPS). }\end{array}$ & $(+)$ \\
\hline $\begin{array}{l}\text { Population ratio } \\
\text { (Population) }\end{array}$ & $\begin{array}{l}\text { As the direct subject using the roads, as population actively moves around, the } \\
\text { economic life of roads decreases more; with adjustment necessary to the length of } \\
\text { district roads in each province, because areas with longer routes may have a smaller } \\
\text { population than those with shorter routes, Central Bureau of Statistics (BPS). }\end{array}$ & $(+)$ \\
\hline $\begin{array}{l}\text { DAK allocation policy } \\
\text { (Policy) }\end{array}$ & $\begin{array}{l}\text { Dummy variable for formula-based ( } 2010-2015 \text { period) as } 0 \text { and proposal-based } \\
\text { ( } 2016-2018 \text { period) as } 1 \text {; reflects a perception of the extent to which policy could } \\
\text { impact the size of the allocation and the absorption of budgets in the regions. }\end{array}$ & $(-)$ \\
\hline Policy * DAK (DAKpol) & $\begin{array}{l}\text { Reflects interaction between DAK allocation policy and DAK realization to } \\
\text { identify the behavior of each policy. }\end{array}$ & $(-)$ \\
\hline $\begin{array}{l}\text { A portion of damaged } \\
\text { roads in the previous } \\
\text { year (LagRoad) }\end{array}$ & $\begin{array}{l}\text { Reflects the perception of the extent to which length of damaged roads in the } \\
\text { current year increases with the extent of damaged roads in the previous year, } \\
\text { CEIC Databased. }\end{array}$ & $(+)$ \\
\hline $\begin{array}{l}\text { Indonesia Democracy } \\
\text { Index (IDI) }\end{array}$ & $\begin{array}{l}\text { Indicates the level of democracy identified through three aspects: civil liberty, } \\
\text { political rights, and institutions of democracy; provides an overview of } \\
\text { government/ bureaucracy performance, legislative institutions (DPRD), political } \\
\text { parties, judiciary, law enforcement agencies, Central Bureau of Statistics (BPS). }\end{array}$ & $(+)$ \\
\hline $\begin{array}{l}\text { Physical spending } \\
\text { (PEXP) }\end{array}$ & $\begin{array}{l}\text { Reflects a link between political competition and public services; uses a share } \\
\text { of the previous year's regional infrastructure spending as one road construction } \\
\text { financing source. }\end{array}$ & $(-)$ \\
\hline $\begin{array}{l}\text { Maintenance spending } \\
\text { (MEXP) }\end{array}$ & $\begin{array}{l}\text { Reflects a link between political competition and public services; uses a share } \\
\text { of the current year's regional infrastructure spending as one road maintenance } \\
\text { financing source. }\end{array}$ & $(-)$ \\
\hline
\end{tabular}




\section{RESULT AND DISCUSSION}

\section{Fiscal Decentralization and Road Quality}

Table 2 shows that DAK used in the road sector does not statistically impact the quality of district roads (especially model 4). However, the correlation between the DAK and the damaged-road ratios is negative, following previous expectations. The change in DAK allocation policy causes the ratio of damaged roads to increase at a significance level of $10 \%$. When the allocation policy changed to being proposal-based, the ratio of damaged roads increased by $4.6 \%$. In addition, the portion of damaged roads in the previous year significantly affected the addition of damaged roads in the current year by $0.4 \%$.

Table 2. The Estimation Model Using The Fixed-Effect Model (FEM)

\begin{tabular}{|c|c|c|c|c|}
\hline Variables & Model 1 & Model 2 & Model 3 & Model 4 \\
\hline \multirow[t]{2}{*}{ DAK } & $-3.45 e-09$ & $-9.73 e-09$ & & $-9.19 e-09$ \\
\hline & (2.00e-08) & (1.41e-08) & & $(1.42 \mathrm{e}-08)$ \\
\hline \multirow[t]{2}{*}{ Percap } & & 0.000136 & & 0.000126 \\
\hline & & (0.000118) & & $(0.000112)$ \\
\hline \multirow[t]{2}{*}{ Population } & & $4.48 e-07$ & & $4.83 e-07$ \\
\hline & & (5.10e-07) & & (4.91e-07) \\
\hline \multirow[t]{2}{*}{ Policy } & & $4.980^{*}$ & & $4.612^{*}$ \\
\hline & & $(2.662)$ & & $(2.566)$ \\
\hline \multirow[t]{2}{*}{ DAKPol } & & $2.61 e-06$ & & $2.53 e-06$ \\
\hline & & $(2.13 e-06)$ & & $(2.09 e-06)$ \\
\hline \multirow[t]{2}{*}{ LagRoad } & & $0.436^{* * *}$ & & $0.416^{* * *}$ \\
\hline & & $(0.112)$ & & $(0.115)$ \\
\hline \multirow[t]{2}{*}{ Polcomp } & $-28.67^{* * *}$ & & $-29.66^{* * *}$ & $-20.92^{* * *}$ \\
\hline & (7.483) & & (8.421) & (7.389) \\
\hline \multirow[t]{2}{*}{ PEXP } & & & 0.0120 & -0.00476 \\
\hline & & & (0.0185) & (0.0166) \\
\hline \multirow[t]{2}{*}{ MEXP } & & & 0.0216 & 0.00857 \\
\hline & & & $(0.0200)$ & (0.0154) \\
\hline \multirow[t]{2}{*}{ IDI } & & & 0.0541 & 0.0718 \\
\hline & & & (0.0916) & $(0.0862)$ \\
\hline \multirow[t]{2}{*}{ Constant } & $42.89^{* * *}$ & 5.317 & $39.67^{* * *}$ & $19.47^{*}$ \\
\hline & $(6.790)$ & (3.682) & $(8.084)$ & $(10.47)$ \\
\hline Observations & 256 & 256 & 256 & 256 \\
\hline R-squared & 0.285 & 0.369 & 0.288 & 0.380 \\
\hline Number of i & 32 & 32 & 32 & 32 \\
\hline
\end{tabular}

Notes: Robust standard errors in parentheses, ${ }^{* * *} \mathrm{p}<0.01,{ }^{* *} \mathrm{p}<0.05,{ }^{*} \mathrm{p}<0.1$

This study's results are consistent with previous empirical studies that in fiscal decentralization, increased spending on infrastructure is expanding and developing toward 
improving its quality (Kis-Katos \& Sjahrir, 2017). Regions that initially lacked infrastructure access began building public facilities with financial support from the central government. However, the context in the problem described earlier is that implementing the DAK budget increases is accompanied by an increase in damage to roads.

Other factors indicating to influence this condition are the trade-off between road construction and maintenance resulting from differences in development priorities and changes in the scheme for determining DAK allocations. This case is similar to the program in Spain. According to research by Albalate et al. (2013), the existence of budget allocations to maintain road quality empirically proven to be safer for road users. But in reality, the program maintenance of the quality of roads in Spain was considered relatively low. This finding implies that the utilization of the infrastructure budget has not been optimal to maintain roads remain conducive and safe for road users. Moreover, Mehari, Z. (2013) also stated that during 1974-2010, the Ethiopian government's budget allocation continued to increase but only impacted the development of road access. Meanwhile, the improvement of road access in rural areas is still not in line with expectations. Both of these conditions indicate that the government should expand the use of the budget to maintain road quality rather than just building new roads.

Furthermore, Figure 1 shows that in 2010-2014, the length of heavily damaged roads tended to be constant, with an average share of 16 percent of total district roads. This finding indicates that road-condition constancy is one of the impacts of road maintenance, even though such roads are still categorized as severely damaged. However, in 2018, damaged roads drastically increased to 24.5 percent. This increase may have happened because, during the 2015-2019 government, one of the priority programs was providing physical road infrastructure, including district roads. District-road development showed a significant increase, reaching 5\% in 2018 .

Figure 1. Comparison of The Length of Damaged Roads and Total District Roads

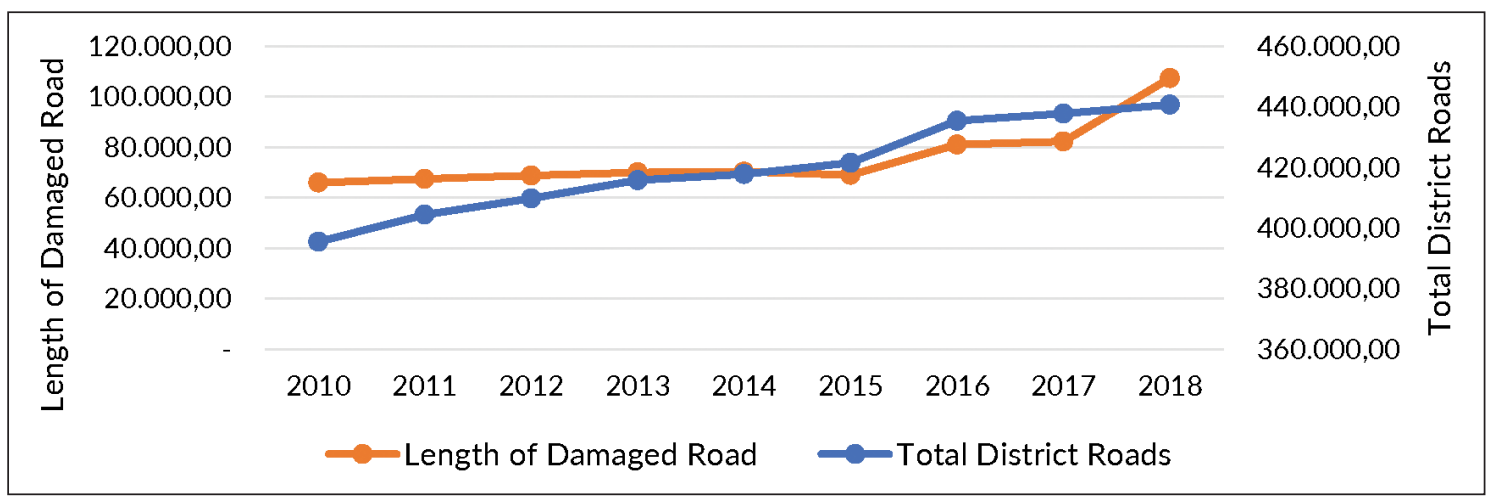

Source: CEIC, 2020 (processed data)

The lack of road infrastructure, especially in the regions, has led to neglect of maintenance activities. The reason behind the budget's neglect for maintaining road quality is often because of the trade-off between new road construction and road maintenance. 
Even though DAK has a positive relationship with road-quality improvement, differences in priorities increase heavily damaged roads. The increasing need for road access in line with economic activity development does not guarantee that the focus is on increasing road length but also on maintaining/improving road quality. The OECD states that ensuring that infrastructure maintenance is carried out regularly and obtaining an adequate budget is crucial and is the easiest way to ensure that the existence and quality of such infrastructure remain conducive to development (OECD, 2016).

In comparing the DAK ratio and the portion of damaged roads, Java and Bali have smaller DAK ratios than other regions; however, the share of damaged roads in these areas is much smaller. Since Java and Bali already have much more adequate infrastructure facilities, the allocation of DAK can focus on road maintenance. Sumatra is also one of the regions with a smaller DAK ratio than the eastern area. However, the share of damaged roads in Sumatra is quite large when compared to Java and Bali. Likewise, the eastern region suggests a dire need for infrastructure development more significantly than other regions. The government focused on allocating much larger DAK for the eastern region and increasing it in 2014. The increasing share of damaged roads in this area is also an indication of the trade-offs described earlier.

The next factor is related to the change in policy for determining DAK allocation from formula-based (top-down) to proposal-based (bottom-up). In 2010-2015 (formulabased), the length of roads in damaged conditions tended to be stable. However, in 2016-2018 (proposal-based), the length of damaged roads increased sharply, indicating that when DAK allocations are prepared based on a proposal-based policy, the portion of district roads that are severely damaged increases. The revised scheme for determining allocations based on local government proposals attempts to improve the effectiveness and efficiency of budget execution. However, from this study's results, the proposed scheme has not yet had the impact expected. The reason is maybe that local governments do not have complete information on the technical guidelines for implementing submissions, resulting in apathy. There is uncertainty from the central government regarding the number of applications received, causing the regions to become skeptical and hesitant to plan developments.

\section{Political Competition and Road Quality}

Table 2 also shows that political competition is consistently negatively and significantly related to the ratio of heavily damaged district roads. Each one-point increase in political competition is related to a decrease in the proportion of district roads in severely damaged conditions by $21 \%$ at the $1 \%$ significance level. Although research has not been found regarding competition and road quality in the Indonesian context, political competition can generally increase expenditure on infrastructure services and increase per-capita income (Rezki, 2018). Increasingly healthy political competition improves the quality of government governance. The elected leader will strive to provide the best performance results to be reelected in the following period (Wiguna \& Khoirunurrofik, 2021). This robust political 
competition indicates that the degree of decentralization is also increasing and can be a way to mitigate the risk of fraud (Dell'Anno \& Teobaldelli, 2015).

The more excellent support has implications for improving the incumbent's performance and will undoubtedly be observable in the services provided (Wiguna \& Khoirunurrofik, 2021). As Burnett \& Kogan (2017) show that the high variation in the number of complaints that arise for local road damage in San Diego is strongly influenced by the extent of local community support for political incumbents. In addition, cities in Colombia, which have high political competition, tend to perform better. This situation is noticeable from the increase in fiscal performance in Colombian cities due to robust political competition (Marín et al., 2021).

Figure 2 shows that each province has a high level of competition and that this level of competition is almost evenly equal across all provinces. This finding suggests a low concentration of political parties in the regions and an evenly distributed concentration of political parties in various areas. Some areas that experienced a strengthening of competition, in general, had fewer damaged roads than other areas in the same region, such as Java, West Kalimantan, East Kalimantan, West Sulawesi, and Central Sulawesi. Regions outside Java also have a high political competition level and are not much different from the Java region itself, such as Kalimantan, Sulawesi, and Papua. However, the share of heavily damaged district roads is still relatively high. This situation may be because local government development outside Java still focuses on developing inadequate road access.

Hayat \& Amaratunga (2014) conducted a study on the maintenance of road infrastructure after the tsunami in Aceh. The result shows that political pressure had an impact on the effectiveness of infrastructure development. However, the project's preference is to prioritize investment in new roads rather than repairing damaged roads. In this case, political stability needs to be reconsidered rather than optimizing the amount of investment to construct new roads. The finding shows that local government performance depends on political power stability and needs support from conducive institutional factors such as political processes.

Figure 2. Political Competition and Damaged-road Ratio

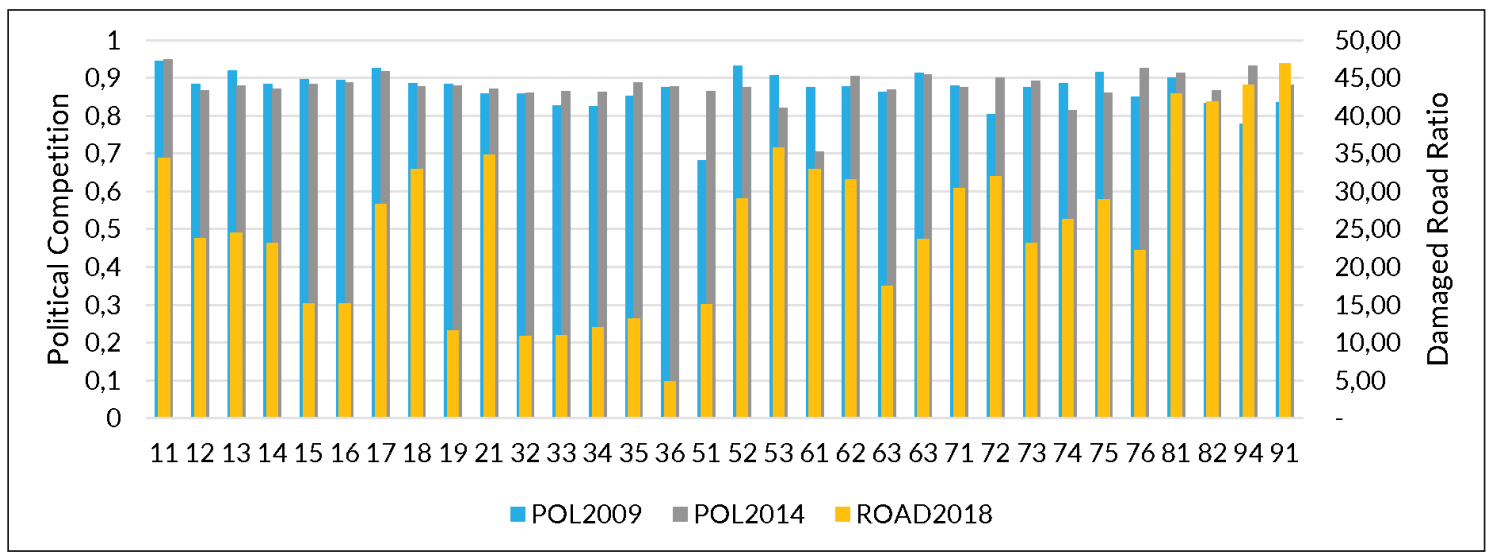

Source: KPU and CEIC, 2020 (processed data) 
The development of political decentralization is also closely related to the strength of democracy. IDI is assumed to show the level of democratic development in Indonesia, which is closely related to the political-system variable. The achievement level is measured based on the implementation and development of three aspects of democracy: civil liberty, political rights, and the institutions of democracy. Overall, the value of the IDI is still classified as moderate, indicating that further improvements to the democratic system are needed. If achieved, such improvements will increasingly reflect the achievement of public satisfaction with available public services. Political rights are an indicator of political democracy that includes participation and competition. There are five main components related to political rights, namely the right to vote, the right to compete for public office, the right to compete for votes, free and fair elections, and the making of government policies based on public votes (United Nations Development Programme, 2009).

The direction of the political-rights aspect seems to be improving. It suggests that citizens' rights to vote and be elected are increasingly open, voters are free to make choices, and the level and impact of public complaints about government administration are also getting better. It also indicates that access to services for the community as related to the political process is getting better. However, the level of political rights is still in the medium category and is the lowest of the aspects measured. The improved level of public trust in the government indirectly impacts improving economic conditions, although this has not been seen optimally in all aspects (Ligthart \& Van Oudheusden, 2015). Therefore, the strengthening of political decentralization must be supported by strengthening the various elements of the democracy index.

\section{Robustness Check}

To ensure that this study's results are robust, the authors involved another independent variable, namely the ratio of the length of a regency's roads to the length of regency roads as a whole. Based on the estimation results in Table 3, the DAK ratio for roads is significantly positively related to the road-length ratio. It suggests that DAK realization is currently focusing on the physical construction of roads. In other words, although the DAK realization has a positive relationship with road-quality improvement, the impact is still not optimal due to differences in the priority scales in budget execution.

It also indicates that the DAK ratio is robust concerning improvement in the quality of district roads but is statistically insignificant. Furthermore, this check found that political competition was negatively related, but the direction changed to positive after using the road-quantity variable. In conclusion, DAK and political competition positively affect the quality and quantity of roads. Moreover, a robust check also considers the ratio measurement of district roads in good condition. Based on the estimation results in Table 4, it is found that DAK and political competition are negatively related to good-quality district roads. This finding indicates that the use 
of DAK and political competition are related to infrastructure problems that are not in good condition. In addition, a road being in good condition indicates that it is newly constructed and therefore does not require maintenance. In conclusion, among the robustness checks, DAK and political competition positively correlate with the improvement of the quality of damaged roads.

\section{CONCLUSION}

The study results indicate that the implementation of DAK was not optimal for improving road quality. It is observable that the absorption ratio of DAK has no impact on advancing the quality of district roads, although the result suggests that the DAK ratio has a negative relationship with the damaged-road ratio. Nevertheless, the differences in priorities of each region have increased districts' damaged-road ratios since the budget for maintaining road quality is often neglected due to the trade-off between new roads construction and road maintenance. In addition, the change in DAK allocation policy, which was initially determined by the central government, to becoming proposal-based has resulted in changes in the behavior of local governments toward DAK requirements.

This study's results, unfortunately, observed that the proposed scheme has not had the optimal impact expected as we observed that the portion of district roads that were severely damaged increased. With a strong relationship between DAK policy and road quality, it is best if regional governments increase socialization about the proposal-based process to encourage small regions to propose the required funds. Additionally, strengthening political competition can positively improve the quality of budget execution and positively impact district roads' quality. Generally, regions outside Java also had high political competition levels and were not much different from the Java region itself.

However, the share of heavily damaged district roads is still relatively high, perhaps because local development outside Java focuses on increasing inadequate road access rather than improving or maintaining existing roads. This study advocates that the central government must set up a better DAK management system to ensure that the planning and budgeting process of local infrastructures development, particularly on road development and its maintanance. Furthermore, the political process in the local budget agreement should rely on the accurate information required and the quality status of local roads.

\section{ACKNOWLEDGMENT}

The authors are thankful to the Indonesia Endowment Fund for Education (LPDP - Lembaga Pengelola Dana Pendidikan) for financial support to carry out this research. 


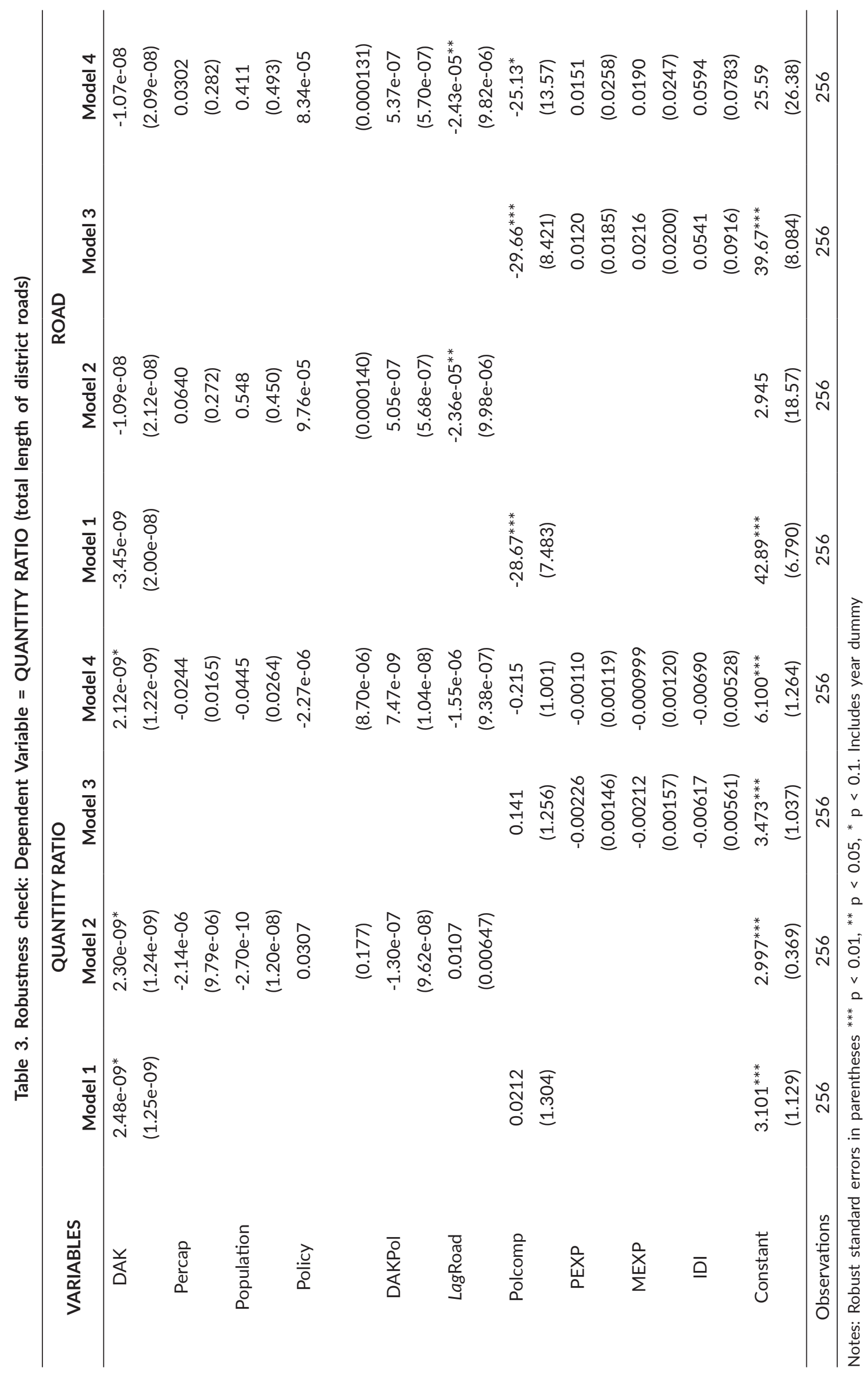




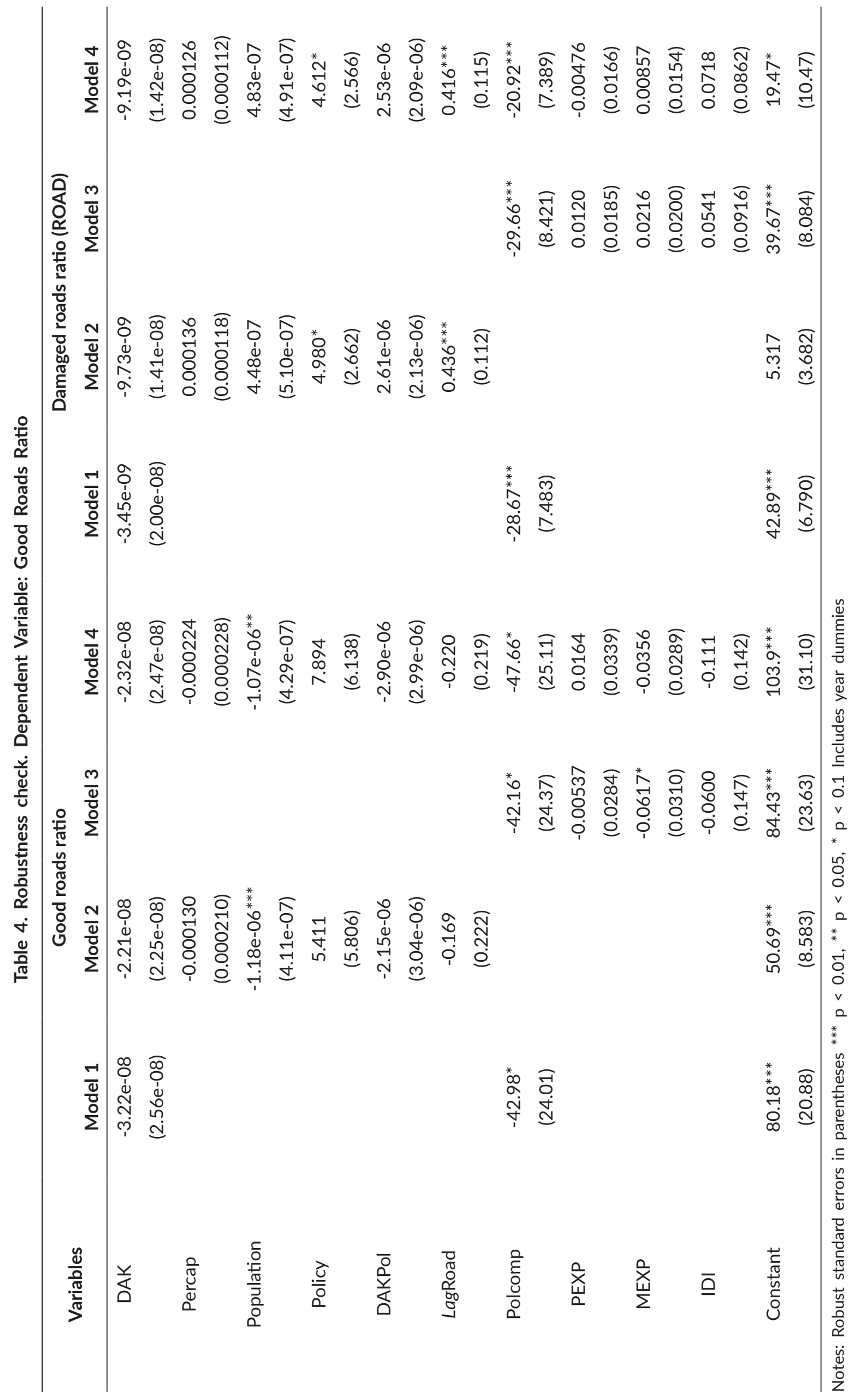




\section{REFERENCES}

Albalate, D., Fernández, L., \& Yarygina, A. (2013). The Road Against Fatalities: Infrastructure Spending vs. Regulation?? Accident Analysis \& Prevention, 59, 227239. https://doi.org/10.1016/j.aap.2013.06.008.

Albornoz, F., \& Cabrales, A. (2013). Decentralization, Political Competition and Corruption. Journal of Development Economics, 105, 103-111.

Alfano, M. R., \& Baraldi, A. L. (2015). Is There an Optimal Level of Political Competition in Terms of Economic Growth? Evidence from Italy. European Journal of Law and Economics, 39, 263-285. https://doi.org/10.1007/s10657-012-9340-5.

Apriliani, A. P., \& Khoirunurrofik, K. (2020). The Impact of Special Allocation Fund (DAK) for Health on Achievements of Health Development Performance in Indonesia. Economies, 8(3), 72-87. https://doi.org/10.3390/economies8030072.

Bracco, E., Porcelli, F., \& Redoano, M. (2019). Political Competition, Tax Salience and Accountability. Theory and Evidence from Italy. European Journal of Political Economy, 58, 138-163. https://doi.org/10.1016/j.ejpoleco.2018.11.001.

Burnett, C. M., \& Kogan, V. (2017). The Politics of Potholes: Service Quality and Retrospective Voting in Local Elections. The Journal of Politics, 79(1), 302-314.

Channa, A., \& Faguet, J. P. (2016). Decentralization of Health and Education in Developing Countries: A Quality-Adjusted Review of The Empirical Literature. World Bank Research Observer, 31(2), 199-241.

del Granado, F. J. A., Martinez-Vazquez, J., \& McNab, R. M. (2018). Decentralized Governance, Expenditure Composition, and Preferences for Public Goods. Public Finance Review, 46(3), 359-388. https://doi.org/10.1177/1091142116639127.

Dell'Anno, R., \& Teobaldelli, D. (2015). Keeping Both Corruption and The Shadow Economy in Check: The Role of Decentralization. International Tax and Public Finance, 22(1), 1-40. https://doi.org/10.1007/s10797-013-9298-4.

Escaleras, M., \& Calcagno, P. T. (2018). Does Fiscal Decentralization Affect Infrastructure Quality? an Examination of U.S. States. Contemporary Economic Policy, 36(2), 410422. https://doi.org/10.1111/coep.12258.

Eyraud, L., \& Lusinyan, L. (2013). Vertical Fiscal Imbalances and Fiscal Performance in Advanced Economies. Journal of Monetary Economics, 60(5), 571-587.

Fan, C. S., Lin, C., \& Treisman, D. (2009). Political Decentralization and Corruption: Evidence from Around The World. Journal of Public Economics, 93(1-2), 14-34.

Fan, S., \& Chan-Kang, C. (2008). Regional Road Development, Rural and Urban Poverty: Evidence from China. Transport Policy, 15(5), 305-314. https://doi.org/10.1016/j. tranpol.2008.12.012.

Ghozali, I., \& Khoirunurrofik. (2020). Fiscal Decentralisation and Capital Expenditure Composition of Regional Government in Indonesia. International Journal of Trade and Global Markets, 13(1), 81-88.

Habibi, N., Huang, C., Miranda, D., Murillo, V., Ranis, G., Sarkar, M., \& Stewart, F. (2003). Decentralization and Human Development in Argentina. Journal of Human Development, 4(1), 73-101. https://doi.org/10.1080/1464988032000051496. 
Hayat, E., \& Amaratunga, D. (2014). The Impact of The Local Political and SocioEconomic Condition to the Capacity of the Local Governments in the Maintenance of Post-Disaster Road Infrastructure Reconstruction Assets. Procedia Economics and Finance, 18, 718-726. https://doi.org/10.1016/s2212-5671(14)00995-2.

Jiménez-Rubio, D. (2011). The Impact of Fiscal Decentralization on Infant Mortality Rates: Evidence from OECD Countries. Social Science and Medicine, 73(9), 14011407. https://doi.org/10.1016/j.socscimed.2011.07.029.

Kappeler, A., Solé-Ollé, A., Stephan, A., \& Välilä, T. (2013). Does Fiscal Decentralization Foster Regional Investment in Productive Infrastructure? European Journal of Political Economy, 31, 15-25. https://doi.org/10.1016/j.ejpoleco.2013.03.003.

Kis-Katos, K., \& Sjahrir, B. S. (2017). The Impact of Fiscal and Political Decentralization on Local Public Investment in Indonesia. Journal of Comparative Economics, 45(2), 344-365. https://doi.org/10.1016/j.jce.2017.03.003.

Lewis, B. D. (2017). Local Government Spending and Service Delivery in Indonesia: The Perverse Effects of Substantial Fiscal Resources. Regional Studies, 51(11), 1695-1707.

Ligthart, J. E., \& Van Oudheusden, P. (2015). In Government We Trust: The Role of Fiscal Decentralization. European Journal of Political Economy, 37, 116-128.

Marín, D. A., Goda, T., \& Tabares Pozos, G. (2021). Political Competition, Electoral Participation and Local Fiscal Performance. Development Studies Research, 8(1), 24-35. https://doi.org/10.1080/21665095.2021.1872394.

Martinez-Vazquez, J., Lago-Peñas, S., \& Sacchi, A. (2017). The Impact of Fiscal Decentralization: a Survey. Journal of Economic Surveys, 31(4), 1095-1129.

Mehari, Z. (2013) Impact of Government Road Sector Spending on Economic Growth in Ethiopia. (Unpublished Thesis). Jimma University.

Neyapti, B. (2006). Revenue Decentralization and Income Distribution. Economics Letters, 92(3), 409-416. https://doi.org/10.1016/j.econlet.2006.03.026.

Neyapti, B. (2010). Fiscal Decentralization and Deficits: International Evidence. European Journal of Political Economy, 26(2), 155-166. https://doi.org/10.1016/j.ejpoleco. 2010.01.001.

OECD. (2016). OECD Economics Survey Indonesia: Overview. OECD. Jakarta.

Rahmawati, F., \& Khoirunurrofik, K. (2021). Planning Consistency and the Political Budget Cycle in Indonesia. Jurnal Ekonomi Kuantitatif Terapan, 14(2) 327-350.

Rezki, J. F. (2018). Political Competition and Local Government Performance: Evidence from Indonesia. Center for Open Science.

Skoufias, E., Bank, W., Narayan, A., Bank, W., Dasgupta, B., Kaiser, K., \& Bank, W. (2011). Electoral Accountability, Fiscal Decentralization and Service Delivery in Indonesia. May 2014. World Bank. Jakarta.

United Nations Development Programme. (2009). Menakar Demokrasi di Indonesia: Indeks Demokrasi Indonesia 2009. UNDP, Indonesia. Jakarta.

Wiguna, G. E., \& Khoirunurrofik, K. (2021). Political Budget Cycle Patterns and The Role of Coalition Parties in Shaping Indonesian Local Government Spending. AsiaPacific Journal of Regional Science, 5(1), 41-64.

World Bank. (2017). Indonesia Economic Quarterly: Decentralization that Delivers. World Bank. Jakarta. 